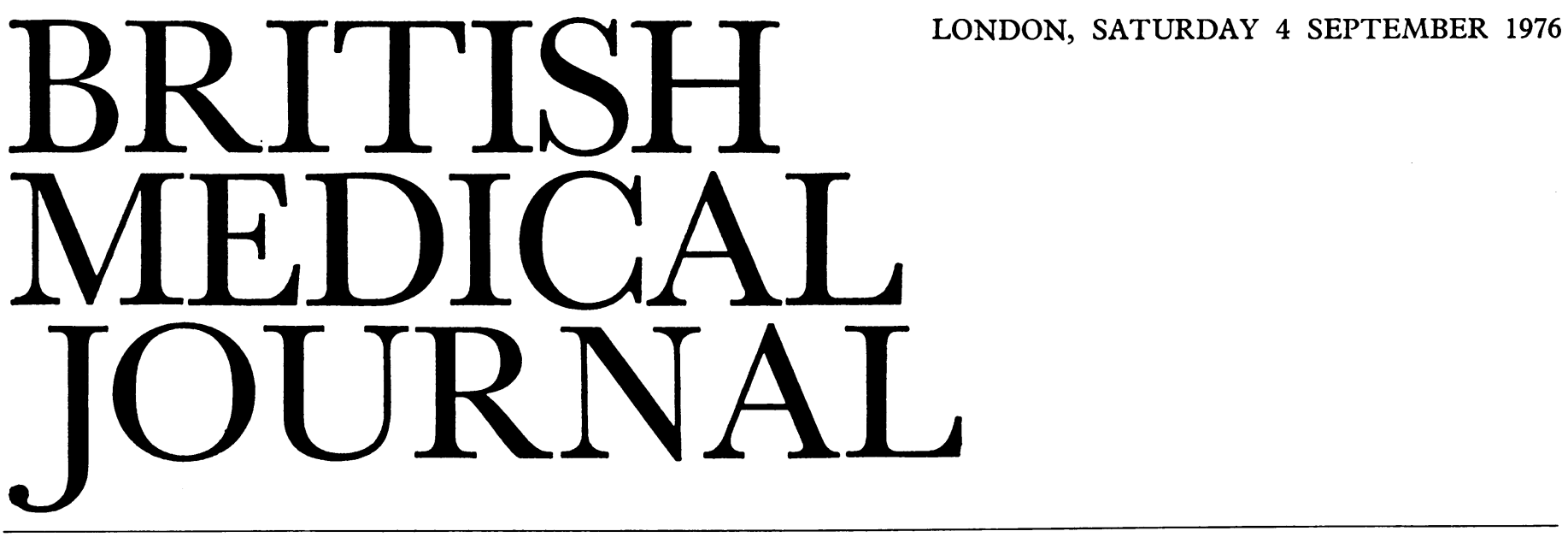

\title{
School pregnancies
}

An unmarried pregnant girl aged between 16 and 19 may pose difficult problems for the medical and social services as well as for herself and her family, but if needs be she is capable of earning some sort of living and there is at least the possibility of marriage. At this age, too, the girl can be expected to take a responsible share in the decision about continuation or termination of the pregnancy. Under the age of 16 the circumstances are different. The girl cannot support herself nor can she marry, and the consequences of the pregnancy, whether or not it continues, are mostly beyond her comprehension. Because of her age the girl's parents or guardians are more likely to become deeply involved.

Until the mid 1950s fewer than 200 girls under the age of 16 had babies each year in England and Wales, but the number has risen steadily in the past 20 years $^{1}$ and reached 1743 in 1973. In that same year there were 3090 legal abortions in this young age group, ${ }^{2}$ making a total of 4833 conceptions. Though the number of babies born to girls under 16 has levelled off in recent years, the demand for therapeutic abortions has continued to rise. Last year ${ }^{3}$ there were 3526 , an increase of $9 \%$ over $1974^{3}$ (over the same period the number of abortions in all other age groups fell by $2 \cdot 5 \%$ ). Provisional figures ${ }^{3}$ for the first four months of 1976 show for the first time a marginal decrease in abortions in girls under 16. Understandably doctors want to help these young girls and their families by terminating the pregnancy, and the abortion rate would probably be even higher if more of the girls sought help earlier. But this issue is being resolved on emotional rather than on scientific grounds, for little is known of the sequelae of therapeutic abortion in the early teens.

There is some evidence to show that the immature tightly closed cervix of the young girl is liable to be damaged during dilatation. Russell ${ }^{4}$ has reported a greater risk of significant cervical laceration in termination in young teenagers than in older primigravidae. (The risk of cervical damage is not overcome by the use of prostaglandins. ${ }^{56}$ ) It has yet to be established whether cervical function may be so disrupted in some cases that there is an increased risk of spontaneous abortion or premature onset of labour in future pregnancies. How relevant are such factors as the girl's age, the development and condition of the cervix, and the duration of the pregnancy? If the pregnancy continues what psychological hazards are there for the girl? What consequences may there be for her parents and other members of the family? How important is the inevitable interruption of the girl's education? What may the effect be upon her career and marriage prospects? To what extent does sexual intercourse at this age increase the risk of cervical cancer in later years? The answers to these questions are largely unknown, though there is enough evidence to suggest that there is cause for concern. ${ }^{4-9}$

For the most part the girls are unwitting victims of attitudes and practices currently fashionable in our society, and they need help. Some authors attribute the rise in the numbers of teenage pregnancies to lack of adequate information on sex and especially to lack of knowledge of birth control methods. ${ }^{10-13}$ Their studies suggest that many pregnant adolescents wanted contraceptive advice and might have prevented their pregnancies had they known how. There are reports of special family planning clinics for the young, ${ }^{14-18}$ mostly aimed to avoid a further pregnancy in those who have already had one. In the short term these may be effective, but less so with the passage of time.$^{15-17}$ Probably the greatest deterrent to the use of contraception by young adolescents is the irregularity of intercourse. A couple with a stable relationship might take suitable precautions to avoid pregnancy, though regular use of contraception increases the risk that their sexual activity will be discovered by their parents, at least when methods other than withdrawal and the safe period are used. Brief talks at school to boys and girls on sex education and contraception are likely to be less successful than longterm programmes offering initial and continuing guidance on all aspects of sexual activity. ${ }^{15}$ But the poorly motivated will fail to attend, and they are the most vulnerable.

Some parents and some sections of society may object to schoolchildren's attention being drawn to sex in this way, and particularly to discussion about contraceptive methods with the implication that their teachers and parents expect them to be sexually active. They would favour educational programmes with an emphasis on self-discipline and attention drawn to the responsibilities that come with sexual activity. The young will not be persuaded easily that self-discipline and responsibility in sexual matters are desirable standards of behaviour in a society which openly condones and even abets sexual permissiveness. Yet it is time that the balance was redressed and a sustained attempt made to describe the dangers and disadvantages of a sexual relationship in early adolescence. Perhaps there are lessons to be learned from industry, where marketing techniques are used to alter people's attitudes and buying habits. A sustained campaign of that kind might, in time, convince adolescent boys that it is not manly, responsible, socially acceptable, or desirable to make girls of 14 or 15 pregnant. Young girls might come to appreciate that pregnancy, 
whether it continues or not, is not without risks and disadvantages for them. And it would do nothing but good for parents of adolescents to be reminded at intervals of the responsibility they have for the upbringing and welfare of their children. This may seem a formidable task, though not an impossible one if sufficient people care about adolescents, and especially about the nearly 5000 young schoolgirls each year in Britain who find themselves pregnant before they have much idea of what life has to offer.

${ }^{1}$ Registrar General's Statistical Review of England and Wales. 1955-1973. Tables, pt II. London, HMSO, 1957-75.

${ }^{2}$ Registrar General's Statistical Review of England and Wales. Supplement to Abortion, 1973. London, HMSO, 1975.

3 OPCS Monitor, AB76/1-5, Legal Abortions. London, Office of Population Censuses and Surveys, 1976.

4 Russell, J K, Clinics in Obstetrics and Gynaecology, 1974, 1, 683.

5 Shearman, R, Smith, I, and Korda, A, Fournal of Reproductive Medicine, $1972,9,448$.

${ }^{6}$ Kajanoja, P, et al, Fournal of Obstetrics and Gynaecology of the British Commonwealth, 1974, 81, 242.

7 Rotkin, I D, Cancer Research, 1967, 27, 603.

8 Coppleson, M, British fournal of Hospital Medicine, 1969, 2, 961.

${ }^{\circ}$ Punnonen, R, Grönroos, $M$ and Peltonen, R, Lancet, 1974, 2, 949.

10 Wearing, M, et al, Obstetrics and Gynecology, 1967, 29, 792.

${ }^{11}$ Kinch, R, et al, American fournal of Obstetrics and Gynecology, 1969, 105, 20.

12 Furstenberg, F, fournal of Marriage and the Family, 1969, 31, 34.

13 Von Der Ahe, C, American fournal of Obstetrics and Gynecology, 1969, 104, 279.

14 Furstenberg, F, fournal of Health and Social Behaviour, 1971, 12, 340.

15 Furstenberg, F, Masnick, G, and Ricketts, S, Family Planning Perspectives, $1972,4,54$.

${ }_{16}$ House, E, and Goldsmith, S, Family Planning Perspectives, 1972, 4, 27.

17 Jekel, J, Klerman, L, and Bancroft, D, American fournal of Public Health, $1973,63,769$.

18 Newton, J, Elias, J, and Newton, P, British Medical fournal, 1971, 2, 642.

\section{Elective surgery and the pill}

The large scale of the prescription of oestrogens as oral contraceptives and more recently as hormone replacement treatment for menopausal symptoms has brought new clinical problems. One of these concerns the policy to be adopted when surgical procedures need to be performed on women taking oestrogens in view of the association between their use and an increased risk of thromboembolism. ${ }^{1-3}$

Oestrogens accelerate blood clotting and platelet aggregation as well as causing changes in the blood vessel wall, ${ }^{4}$ all of which may be factors in intravascular clotting. The first two are more easily studied. Oestrogen-progestogen combinations used as oral contraceptives accelerate the broad-spectrum clotting tests, the prothrombin time, and partial thromboplastin time, and cause rises in specific clotting factors, namely, factors I (fibrinogen), II (prothrombin), VII, VIII, IX, and $X^{5-9}$ In addition, reduction of antithrombin III $^{1011}$ and increases of antiplasmins ${ }^{12}$ and of antiactivators of fibrinolysis have been held to be concomitant factors in the production of a hypercoagulable state. Increased platelet aggregation with collagen and thrombin has also been observed after administration of oestrogen. ${ }^{15-16}$ Changes in the coagulation system have been reported too when oestrogen alone has been given as hormone replacement therapy. ${ }^{17}$ In contrast progestogens given alone do not produce appreciable changes in clotting factors. ${ }^{18}$

While the epidemiological and coagulation studies have been widely accepted as clear evidence of the increased risk of thromboembolic disease during oestrogen therapy, controlled clinical evidence has been scanty. ${ }^{19}$ Nevertheless, a recent prospective trial by Sagar and co-workers ${ }^{20}$ using the radio- iodine fibrinogen uptake test has clearly shown that patients who have taken oral contraceptives during the months before surgery have an increased incidence of postoperative deep vein thrombosis.

Clinicians should therefore consider what action is justified to take account of this risk. Withdrawal of oral contraceptives for four or six weeks before surgery is of doubtful rationale. Some of the changes in clotting factor persist for weeks or months after the discontinuation of oestrogens. ${ }^{21}{ }^{22}$ Furthermore, there is a risk of unwanted pregnancy while the woman is waiting for her operation, for substitute contraceptives are likely to be less reliable. Each case warrants individual assessment. The additional thrombotic risk could be minimised by prophylaxis with low-dose heparin or possibly, where facilities are available, mechanical stimulation of the venous return (without stopping oral contraception), and such treatment may indeed be justified for all but minor surgical procedures. ${ }^{23}$

${ }^{1}$ Vessey, M P, in Recent Advances in Thrombosis, ed L Poller, p 39. Edinburgh and London, Churchill Livingstone, 1973.

2 Oral Contraceptives and Health-An Interim Report from the Oral Contraception Study of the Royal College of General Practitioners. London, Pitman, 1974.

${ }^{3}$ Kay, C R, Lancet, 1975, 1, 1381.

4 Ulutin, O N, in Recent Advances in Blood Coagulation, ed L Poller, p.215. London, Churchill Livingstone, 1969.

5 Thomson, J M, and Poller, L, British Medical fournal, 1965, 2, 270.

6 Poller, L, Tabiowo, A, and Thomson, J M, British Medical fournal, 1968, 3, 218.

Egeberg, O, and Owren, P A, British Medical fournal, 1963, 1, 220.

${ }^{8}$ Hougie, C, et al, Metabolism, 1965, 14, 411.

${ }^{9}$ Nilsson, I M, and Kullander, S, Acta Obstetricia et Gynecologica Scandinavica, 1867, 46, 286.

10 von Kaulla, E, and von Kaulla, K N, Lancet, 1970, 1, 36.

11 Howie, P W, et al, Lancet, 1970, 2, 1329.

12 Phillips, L L, Turksoy, R N, and Southam, A L, American fournal of Obstetrics and Gynecology, 1961, 82, 1216.

${ }^{13}$ Brakman, P, Albrechtsen, O K, and Astrup, T, fournal of the American Medical Association, 1967, 199, 69.

${ }^{14}$ Hilden, M, Amris, C J, and Starup, J, Acta Obstetricia et Gynecologica Scandinavica, 1967, 46, 562.

15 Davies, T, Fieldhouse, G, McNicol, G P, Thrombosis and Haemostasis, 1976, 35, 403.

16 Poller, L, in Recent Advances in Thrombosis, ed L Poller, p 181. Edinburgh and London, Churchill Livingstone, 1973.

17 Coope, J, Thomson, J M, and Poller, L, British Medical fournal, 1975, 4, 239.

18 Poller, L, et al, British Medical fournal, 1969, 1, 554.

19 Goldzieher, J W, and Dozier, T S, American fournal of Obstetrics and Gynecology, 1975, 123, 878.

20 Sagar, S, et al, Lancet, 1976, 1, 509.

${ }^{21}$ Poller, L, Thomson, J M, Thomas, W, British Medical fournal, 1971, 4, 648.

22 Dugdale, M, and Masi, A T, in Second Report on Oral Contraception by the Advisory Committee on Obstetrics and Gynecology, Washington ED US Department of Health, Education and Welfare Food and Drug Administration. 1969.

23 Sabri, S, et al, British Medical fournal, 1971, 3, 82.

\section{HLA and disease: a conundrum}

What do dermatologists, neurologists, mouse geneticists, human geneticists, Nobel prizewinners, gastroenterologists, surgeons, tissue typers, paediatricians, and rheumatologists have in common? One answer is an interest in the major histocompatibility complex (MHC), and in Paris from 23 to 25 June it brought these individualists together. The MHC is a system of closely linked multiple genes known in man as the HLA region. ${ }^{1-3}$ These genes are located on chromosome 6 and include the $\mathrm{A}, \mathrm{B}$, and $\mathrm{C}$ loci controlling cell surface glycoproteins detectable serologically, the $\mathrm{D}$ locus controlling cell 